\title{
ARTICLE
}

\section{Moving Towards Sustainable Outcomes in Student Partnerships: Partnership Values in the Pilot Year}

\author{
*Jenny Marie and Susannah McGowan, UCL Arena Centre for Research-based Education, \\ University College London (UCL), United Kingdom
}

Contact: j.marie@ucl.ac.uk

\section{ABSTRACT}

The UCL ChangeMakers scheme supports students and staff to work in partnership to enhance the University College London (UCL) learning experience. In 2014/15 we piloted the scheme with 10 projects run by 24 students in collaboration with 11 staff members. This paper will focus on our evaluation efforts of the pilot year through 4 illustrative case studies highlighting the successes and challenges of 4 projects. We focused our discussion on how projects were defined, what role students and staff should have had in defining the projects, and the sustainability of the projects once the student moves on or graduates. From our case study analysis, our findings revealed that a series of partnership values - collective responsibility, honesty, plurality, and trust-need to be considered in order to have an impact on the sustainability of the project and, more importantly, on the learning experience for students.

\section{KEYWORDS}

students as partners, sustainability, learning enhancement, students as change agents, student engagement

Increasingly, students in higher education are invited to act as partners in curricular processes designed to enhance engagement and ownership in their own learning process. The scope for such work is wide ranging, with students acting as members of course design teams (Mihans, Long, \& Felten, 2008), consultants working through classroom observations (Cook-Sather, 2014), and partners on projects focused on affecting change in teaching and learning.

UCL ChangeMakers is an initiative at University College London (UCL) that fosters, sustains, and supports partnership projects focused on changing current teaching and learning practices. $\mathrm{UCL}$ is a research-intensive university with a full range of academic disciplines. It has approximately 38,000 students, almost 18,000 of whom are undergraduates. It is currently working hard to enhance its educational provision with the aim of securing the same high reputation for education that it has for research. One of the 
objectives of its 20-year vision, UCL 2034, is to ensure students are "full partners in the future of UCL" (UCL, 2014).

Currently in its fourth year, the UCL ChangeMakers initiative has progressed and evolved from a "students as change agents" model (Dunne \& Zandstra, 2011), which has arisen in the UK from the University of Exeter scheme of the same name. UCL ChangeMakers has moved away from this model, whereby the university empowers students to initiate and run their own enhancement projects towards a model where students work as partners alongside staff, determining and carrying out projects collaboratively.

At the start of the pilot year of the initiative, a call was sent out to all UCL students via staff to participate in the pilot UCL ChangeMakers scheme. The call asked students if they had an idea for how to improve the UCL education experience in exchange for a small stipend, with students on a project sharing $\mathrm{f200}$. We received twenty project proposals. There was no selection criteria process in place, and while 20 projects began, this reduced to 10 projects over the following six months. No record was kept of student reasons for dropping projects.

The participating students met with UCL ChangeMakers staff to outline projects and were advised to find a staff partner to align their projects to discipline-specific advice and support. A total of 24 students worked in teams on the 10 projects, with each team working with one or two staff partners. UCL ChangeMakers staff provided generic advice and support around suggested research practices and practical matters related to booking rooms and catering. The projects began throughout the academic year and while they officially ran until the end of June, few continued beyond the exam period beginning in March.

In this first year, students reported high levels of satisfaction with the initiative and large personal gains such as an enhanced sense of community and belonging, a sense of empowerment, improved teamwork and communication skills, and a better understanding of how the university works. Comments in the end-of-project questionnaire included:

- "Taking part in an initiative like this really enhanced the sense of community that UCL holds"

- "I feel a bit more like a part of UCL"

- "It made me feel like I could do something beneficial for our community on campus. It felt like everything that I was being taught in university was coming into fruition"

- "It allows for connecting with other members of UCL and with your own classmates. It is a way to enhance team skills and to learn how to communicate ideas"

- "It made me understand better how the behind-the-scenes works at UCL."

On the surface this was a highly successful pilot year. Our working assumption at the time was that as the students' work was directed towards enhancing the learning experience at $U C L$ there would be gains in that area. However, our decision to evaluate the projects a year later prompted us to question our initial assumptions and focus on what happened to the projects and what student and staff perceptions yielded in terms of their own lessons learned from the pilot. 
The case studies discussed here emphasise the necessity of (a) defining the project in partnership, (b) the establishment of a collective sense of responsibility, and (c) a firm belief that students can achieve change. Taken in combination, we believe these values will lead to the sustained impact of educational enhancement projects driven by students. The cases also highlight important distinctions between the change-agents model (the starting point for the UCL ChangeMakers initiative) and students as partners model (the model UCL ChangeMakers used after the pilot year) as highly relevant for understanding the sustainable impact of such projects.

\section{SITUATING UCL CHANGERMAKERS IN THE STUDENT PARTNERSHIP LITERATURE}

The benefits of student partnership have been well documented, and, indeed, we were able to trace many benefits in the first year of UCL ChangeMakers. Our evaluation documented not only the educational enhancement but also how this enhancement was (or was not) sustained after the project ended. UCL partnership work is guided by the current scholarship on partnership: the benefits, the challenges, and how such schemes operate within traditional institutional infrastructures.

Evaluations of local schemes have previously shown that partnership educational enhancement projects can have high immediate impact. For example, at the end of its first year, the Winchester Student Fellows scheme had resulted in a large number of small institution-wide changes, such as online learning resources (El-Hakim, King, Lowe, \& Sims, 2016). Similarly, at Northampton, the URB@N scheme has led to changes to enhance the student learning experience, such as changes to the library induction (Maunder, 2015). However, there is little evidence of the impact of such work being sustained as yet, as these evaluations occurred at the end of the projects.

In investigating sustained impact, a question emerging from this paper is to what extent control should be passed over to students, especially as UCL ChangeMakers moved from the change-agents model to a students-as-partners framework. Dunne and Zandstra (2011) distinguish the students-as-change-agents model as students setting the agenda, whereas partnership usually occurs with a more explicit negotiation between staff and students. However, this distinction has become blurred in recent years. Healey, Flint, and Harrington (2016) explicitly categorise Exeter's "students as change agents" scheme as partnership work in the area of Scholarship of Teaching and Learning. We argue in this paper that the change-agents model is closer to students in control than to partnership in Bovill and Bulley's (2011) version of Arnstein's ladder of participation. The importance of the distinction for sustained impact is particularly shown in the case studies we discuss below.

Better established in the literature are the benefits for participants and institutions. For the participating students and staff, immediate benefits include enhanced motivation, engagement, and learning, with students and staff gaining awareness of how they think and who they are (Cook-Sather, Bovill, \& Felten, 2014). Healey, Flint, and Harrington (2014) add the development of a sense of community, which aids student attainment and retention.

The benefits for institutions in running partnership schemes include the move to a more democratic, collaborative culture. Student partnership can challenge neoliberal economic conceptions of higher education, enabling the institution to recalibrate its purpose as students take more responsibility for their own learning (Dunne \& Zandstra, 2011; Cook-Sather et al., 2014). Åkesson and Malmberg (2012) point out that student partnership is a way to increase educational quality at relatively low economic cost. 
Partnership work also improves students' development and employability skills (Andersson, 2012; Jarvis, Dickerson, \& Stockwell, 2013).

Despite the high-impact benefits of partnerships, there is often resistance to partnership from both staff and students. Resistance among staff might stem from the need to reconceptualise learning and teaching and moving away from practices that had suited them as students to more inclusive ones (Cook-Sather et al., 2014; Cook-Sather, 2014). For many staff, time is a major factor in being part of partnership schemes in addition to normal workloads; the other factor is professional recognition for engaging in this work (Bovill \& Bulley, 2011). Both time and the question of how this work relates to the promotion process might yield reluctance and hesitation from staff.

Staff may also be concerned about whether students have the requisite knowledge and expertise, and students may prefer working in the passive, traditional student role (Bovill, Cook-Sather, Felten, Millard, \& Moore-Cherry, 2015). While sources of student resistance to partnership work are not well reported in the literature, student resistance could develop from a consumerised higher education sector; in other words, why should students do work they are paying fees for? We contend these particular forces play a role in the sustainability of partnership projects, not least because they are linked to multiple, complicated misperceptions, such as the perception held by staff and students that students cannot play a role in changing educational practice. A common misperception among students pertain to staff not having time to contribute to the project. Our case studies explore these perceptions and implicit frustrations that can affect the sustained impact of projects.

\section{METHODOLOGY AND ANALYSIS}

Our main research questions centred on students' experience within their project and staff and student perceptions of the impact of their projects. We used data gathered at two points in time: at the completion of the project timeframe in 2015 and one year after this date in the summer of 2016.

An anonymous online survey was used to seek feedback on the scheme in June 2015 (questions are shown in Appendix 1). The response rate was 29\%, with seven out of 24 students responding. The low response rate was probably due to the timing of the survey because most students had completed their studies by June. However, as the projects were allowed to continue until the end of June, this was deemed the most sensible time for the survey. To gauge sustainability of the completed projects, one question concerned how likely the students thought it was that a change would occur based on their completed project. On a scale of 1-5, where 5 was "very confident" a change would occur, three students rated the likelihood of change as 3 , two of them as 4 , and two as 5 . Five students gave reasons for their ratings: Three said they were confident because they had received positive feedback, one because it linked to an institutional strategy, and another student was hopeful that the university was committed to improving and taking student views into consideration.

In addition to the final survey, the 24 students were each asked to provide a case study at the end of the 2015 spring term. Recorded interviews were held with students from four of the 10 projects; a separate group submitted their own video while another group submitted PowerPoint slides. Many of the projects were not completed at this point, but they provide an outline of what had been achieved at that point in the project lifecycles. The failure to submit a case study did not imply that the project was not completed or 
successful. Staff have subsequently provided feedback and materials that the students themselves did not submit.

In 2016, we invited students and their staff partners to complete separate online surveys about the impact of the projects. Only three students (13\%) and one staff member (10\%) completed the survey. Within the survey, we asked who would be amenable to an interview; by chance both the former student and staff from the same project, "Assessment and Feedback" in Laws agreed to be interviewed. The agreement of the former Laws student to be interviewed was an anomaly; the interview occurred via Skype. The low response rate among students in general was due to many students no longer being at UCL. Another reason could be that we did not initially set up the year-on survey as an expectation of participating in partnership. The low response rate from staff could have been due to minimal engagement at the outset of the project; therefore participating in a survey a year later did not make sense.

Following this disappointing response rate to the survey from students and staff, we then emailed the staff partners directly at the start of August 2016 to ask what the impact of the project had been and what, if any, lessons they thought could be learnt to maximise the impact of the projects in future. Email communication proved more successful as seven staff replied to the UCL ChangeMakers director. We felt that staff were in a better position to inform on any lasting effects of the project, as most students were no longer at university. Therefore the interpretations of project impact were only taken from the staff perspective for many of the projects. Further work to plan and gather student perspectives would be helpful in future research projects.

We used an interpretivist, grounded approach (Charmaz, 2014) when analysing what we had gathered. We were reliant upon participants' perceptions and interpretations of whether the project had had an impact and the factors that had influenced that. Through triangulating the final evaluations, online surveys, email communications, and interviews, we were able to piece together stories of impact as well as stories where impact was not possible due to miscommunication or misunderstanding. These data points further allowed us to outline factors that influenced the sustainability of the projects, which will be described in detail in our case studies. The limitation of the low response numbers make it impossible to generalise our findings; yet, taken together they provide useful perspectives and insight into what is needed in partnerships to garner sustainable educational impact.

Participant quotes come from the interviews and online surveys conducted a year after the projects ended and interviews at the end of the projects.

\section{FINDINGS}

The table below shows the activity of 10 projects from the first year: what happened during the year, project outputs and what, if any, sustainable outcomes the project had following the project's completion. Four of the projects will be discussed in depth as cases representing important questions to be asked of student-staff projects. Collectively, the case studies emphasise the importance of partnership for sustained impact, the characteristics of partnerships, and the challenges faced when trying to achieve this through a change-agents model. Furthermore, each case study poses an important question to consider when thinking about how to foster effective student-staff partnerships. 
Table 1. Overview of project outcomes

\begin{tabular}{|c|c|c|}
\hline PROJECT TITLE & OUTPUTS FROM THE PROJECT & SUSTAINABLE OUTCOMES \\
\hline $\begin{array}{l}\text { Intercalating } \\
\text { Bachelor of } \\
\text { Science (iBSc) } \\
\text { Reforms }\end{array}$ & No information. & $\begin{array}{l}\text { No information: assumed no sustainable } \\
\text { outcome. }\end{array}$ \\
\hline $\begin{array}{l}\text { Second Language } \\
\text { Learning }\end{array}$ & $\begin{array}{l}\text { Skype exchanges between } \\
\text { approx. } 12 \text { UCL and } 12 \\
\text { Columbian students; Wiki page } \\
\text { also created. }\end{array}$ & $\begin{array}{l}\text { Though the department attempted to rerun } \\
\text { the Skype exchanges there was no student } \\
\text { uptake in } 2015 / 16 \text {. }\end{array}$ \\
\hline $\begin{array}{l}\text { Assessment and } \\
\text { Feedback }\end{array}$ & $\begin{array}{l}\text { Document produced and } \\
\text { disagreement between student } \\
\text { and department as to whether } \\
\text { it was delivered. }\end{array}$ & $\begin{array}{l}\text { No outcome possible as staff do not recall } \\
\text { receiving the report. }\end{array}$ \\
\hline Module Database & $\begin{array}{l}\text { Identified need for a better } \\
\text { system for module choice. }\end{array}$ & $\begin{array}{l}\text { Staff provided feedback that there was no } \\
\text { sustainable outcome. }\end{array}$ \\
\hline $\begin{array}{l}\text { Belonging and } \\
\text { Attainment }\end{array}$ & $\begin{array}{l}\text { Demonstrated a belonging gap, } \\
\text { correlated to the attainment } \\
\text { gap for black and minority } \\
\text { ethnic (BME) students }\end{array}$ & $\begin{array}{l}\text { Project findings raised in two meetings with the } \\
\text { Vice Provost (Education and Student Affairs). } \\
\text { Planning new projects on belonging and } \\
\text { enhancing the breadth of cultural capture in } \\
\text { the degree. }\end{array}$ \\
\hline PhD Forum & $\begin{array}{l}\text { Demonstrated a need for an } \\
\text { online platform to encourage } \\
\text { communication, collaboration, } \\
\text { and knowledge and skills } \\
\text { exchange and a women's forum } \\
\text { to help them transition from } \\
\text { their PhD into a career. }\end{array}$ & No information available. \\
\hline $\begin{array}{l}\text { Curriculum } \\
\text { Review to } \\
\text { Identify Syllabus } \\
\text { Overlaps }\end{array}$ & $\begin{array}{l}\text { A number of issues about the } \\
\text { programme were discussed } \\
\text { amongst the student body and } \\
\text { eight PowerPoint slides were } \\
\text { delivered. }\end{array}$ & $\begin{array}{l}\text { Comments in the National Student Survey } \\
\text { (NSS) had a high degree of similarity to the } \\
\text { PowerPoint slides, leading to a major rethink } \\
\text { about the nature and structure of the } \\
\text { programme. }\end{array}$ \\
\hline $\begin{array}{l}\text { Moodle Best } \\
\text { Practice }\end{array}$ & $\begin{array}{l}\text { Moodle Site Best Practice Guide } \\
\text { produced. }\end{array}$ & $\begin{array}{l}\text { The guidelines were discussed by staff. At a } \\
\text { student-staff meeting in 2015, students } \\
\text { reported that the majority of Moodle sites are } \\
\text { much easier to follow. }\end{array}$ \\
\hline $\begin{array}{l}\text { Clinical-Based } \\
\text { Learning and } \\
\text { Medical } \\
\text { Illustration }\end{array}$ & $\begin{array}{l}\text { Trialled problem-based learning } \\
\text { in one lecture and } \\
\text { demonstrated through student } \\
\text { feedback that it had improved } \\
\text { their learning. }\end{array}$ & $\begin{array}{l}\text { Piloted a clinical problem-based scenario in } \\
2015 / 16 \text { with mixed response from students } \\
\text { but overall improved student engagement. } \\
\text { Plans to expand on this in } 2016 / 17 \text {. Successfully } \\
\text { applied for funding from UCL ChangeMakers in } \\
2016 / 17 \text { to include illustration-based learning } \\
\text { and to pilot drawing in the course. }\end{array}$ \\
\hline $\begin{array}{l}\text { Student } \\
\text { Academic } \\
\text { Engagement }\end{array}$ & $\begin{array}{l}\text { Report making } \\
\text { recommendations in } 12 \text { main } \\
\text { areas. }\end{array}$ & $\begin{array}{l}\text { Changes have been made in at least seven of } \\
\text { the areas in which recommendations were } \\
\text { made. }\end{array}$ \\
\hline
\end{tabular}




\section{Case study 1: How should partnerships be defined? And who should define them?}

When the UCL ChangeMakers announcement appeared in her email inbox, a fourth year student in Laws, Bethi, applied immediately and cited her goal to investigate changes to final year modules. Her written proposal stated that her project would aim to introduce opportunities for team work as a form of formative assessment into the Faculty of Laws. The staff member involved in the project also remembers the student's wish to explore the incorporation of group work in the curriculum. The staff member recalled the idea as innovative, and she applauded the student for recognising the need to connect academic group work to group work that might happen within a law firm. After their first project meeting, the staff member thought Beth would pursue this question in her project.

There were only two meetings between the staff member and Beth throughout the project: the initial meeting to discuss the project and the second-term meeting to discuss progress. Beth felt that the member of staff was too busy: "We just felt like we could do it along with it and obviously someone who is a staff who does not have time to be involved and our project was changing so much so I think at some point we lost the connection with the staff member" (Interview a year after the project). Meanwhile, the staff member clearly felt that it was not her place to reach out to the student: "I remember having this conversation when I was saying, 'how do we know what is happening in the project?' And we don't. It could have been purely this case. This student got distracted and did not close the loop or she may have done more and did not tell me about it" (Interview a year after the project). Uncertainty over communication marred the project from the outset.

The middle of the project produced many questions for the staff member around what was happening - particularly about how to receive and give guidance to the student. At their second meeting, the staff member discovered the student had shifted the project focus to gathering feedback on improving timely essay feedback. In fact, in her interview a year after the project had ended, the student said the project goal had always been more about timely feedback on formative essays.

The staff member was disappointed to learn the student had switched project topics midyear as she felt the department had already gathered information about timely feedback on essays and they were in the process of improving it. In particular, she was unsure if she could have told the student what to work on at that point, when it became clear to her that the student work would be of little benefit to the department. She said: "My initial understanding, and it is probably wrong, but my initial understanding was students are to set the agenda and they tell you the things they feel need to be changed. So we don't want to take over. So I don't know" (Interview a year after the project). While the tutor's understanding of a student as change agent may have been correct, the midyear switch presented the staff member with a sense of time wasted over issues already known to the department.

Finally, there is no final report that anyone can currently produce; the student stated she submitted a report to the tutor; the tutor said she did not receive a report from the student. The concerns reported here indicate that there was insufficient communication between the student and staff partner to ensure that they agreed on and defined the project's purpose, or that they returned to that purpose throughout the project and that it remained relevant and useful to all stakeholders. 


\section{Case study 2: Whose responsibility is it to continue the work?}

A Spanish and Latin American Studies student in his second year, Dan, who proposed and ran a project titled, "Second Language Learning," identified a need to provide more opportunities for students in his programme to practise their oral language skills. He therefore arranged an online exchange with a Columbian university. During the project year, 12 UCL students partnered with Columbian students to discuss predetermined topics during Skype sessions. In between Skype sessions, Dan built a Wiki page for them to practise their written skills. Anecdotally, the student response to these activities were very positive; according to both the student and a tutor in the department, although no official evaluation was carried out.

The relationship between the student and staff partner was not very strong. In an online survey conducted a year after the project was completed, Dan reported: "I didn't have very much contact with my staff partner. A member of my department said that they would be happy to support me when I asked at the departmental student-staff meeting, but I didn't have a time when I felt it appropriate to call upon this help." As such, the project was student-led but not necessarily a partnership.

At the end of the project the student described his experience as empowering: "It's empowered me.... Whereas before I think I was content to be a consumer ... of education here at UCL, the ChangeMakers project has allowed me to conceive [of] myself in a producing role" (Interview with Dan).

A year later, the student reported that while the exchanges had initially worked very well, interest had faded. He had studied abroad as part of an exchange program the following year and no online exchanges between UCL and Colombian students had been organized. As a result, in the student survey a year after the "Second Language Learning Project" ended Dan wrote: "I don't think that the project had an overly large impact in my department."

A year after the project, a tutor in the department informed us that at Dan's request he had sent out an email asking for volunteers to participate in an exchange the following year but received no responses to either this email or a subsequent one that was sent at the request of the Columbian instructor. The tutor was clear that this failure was not due to a lack of need. At the time, the current student cohort requested additional classroom language instruction.

Two students, who the tutor characterized as "keen, diligent students," had initially volunteered to take over facilitating the exchange but he was uncertain whether they had done so. He explained that staff could have taken this forward, in particular by integrating it into a core Spanish language module, but staff were too busy to implement this. This would indeed have been a productive, relevant way forward, yet responsibility for sustaining and dissemination of the idea fell to the tutor. Integration of the Skype exchanges into a core module would have been more likely to occur if the project plan had included plans for dissemination of ideas to module coordinators suggesting where to embed and integrate materials. It also brings into question not only the responsibility of the student or tutor but also the question of who will advocate for continued changes to core modules in a programme. 


\section{Case study 3: How will project findings be shared and how will they be most useful for sustainability?}

Two dissatisfied students, Fred and James, were challenged by departmental staff to take on a project to review their course curriculum in order to identify overlaps, which when eliminated would create more time for students to pursue their individual interests. The aim of staff in challenging the students in this way was to convert their dissatisfaction into a force for positive change. The "Syllabus Overlaps" project was the most controversial in terms of its outcomes. The only information on this project comes from the staff involved in the project. They report that the students stayed in touch, with over four meetings occurring between them and the students. However, the staff reported in the 2016 survey that while they received a PowerPoint presentation from the students, they did not receive a final report.

In the survey a year later, a member of staff reports that the students talked a lot to other students in the department and that they catalysed concerted efforts against a member of staff to complain about their module in their responses to the UK's National Student Survey (NSS). Another staff member wrote in an email that the issues raised by Fred and James were not unreasonable, but the way they reported them was very unfair. Following the NSS results, the department had undertaken a major reflection about the nature and structure of the programme. Nonetheless, staff felt strongly dissatisfied with the project.

There is no evidence of the students asking others to put their findings as comments in the National Student Survey, and it would be surprising if their findings and the survey did not reflect the same student views. Nevertheless, there was a staff perception that the students acted unethically, and that while the project has resulted in educational enhancements it has also undermined efforts to develop a culture of student partnership. The irony of this is that if the students acted in this way, they were probably motivated by a sense of powerlessness to effect change through the project. This could have been a symptom of the weakness of the partnership element present in this project.

\section{Case study 4: What can students achieve?}

The "Student Academic Engagement" project was, on the face of it, one of the most successful in terms of delivering positive change. The project was broadly envisaged as trying to identify possible enhancements to the programme. The student, Eva, recruited both students and staff to advise on the project. Eva then conducted a survey and series of focus groups to gain student input. She had weekly meetings with her staff partner, a teaching administrator, and her student team. Towards the end of the project when interviewed, Eva was very confident that her project would bring about change because she had strong support from the teaching administrators.

A year later, a teaching administrator in the department reported that of the 12 areas in which the report made recommendations there had been changes in at least seven of them. She was unclear whether change had occurred in an eighth area and the final 4 were about particular modules or areas of study, where content and delivery is continually reviewed and updated. The administrator reported that there is a strong relationship between academic staff and teaching administrators and that all recognise the importance of engaging with students and taking their feedback seriously. The major barrier (also reported by the student at the time) was that of time for the project. She continued to say that the major lesson to be learned from the project is that students should not restrict 
themselves and that even big changes may be possible. One of the recommendations that did not appear in the report was about the restrictions there were on module choice in years 2 and 3 because the students thought it could not be changed. These restrictions have now been changed for students entering from 2017/18.

A word of caution came from one of the academic staff, who noted that the findings of the report were in line with staff perceptions and that he doubted action would have been taken so swiftly if this had not been the case. He stated that the actions were thus not due (or at least solely due) to the project. It is of course entirely right that changes should only be made quickly where views are aligned: Cook-Sather et al. (2014) emphasise that neither partner's views should override the others. However, this does not mean that the students' work did not deserve any credit for the change.

\section{DISCUSSION: WHAT CAN WE LEARN FROM THE CASE STUDIES?}

Across the four case studies, we found a number of factors that could have contributed to fruitful, sustainable outcomes for each project: defining the project as a partnership at the outset, considering who has responsibility for sustaining the project, establishing trust, and acknowledging what students can achieve. Additionally, our findings show positive moments where partnerships enhanced educational processes leading to sustained impact.

\section{Definition of the project in partnership}

The first case study highlights the real need for the project to be defined as a partnership and the importance of partnership values (Higher Education Academy, 2014). This project would have benefitted from a sense of collective responsibility for the results, with open and honest dialogue about what would be useful to the department. The staff member was right that she could not demand to change the focus for the project in the middle of the project. However, if she wanted to sustain a partnership, she and the student could have addressed the misalignment of objectives and how the project would not be useful to the department. Yet, the staff member was uncertain about the parameters of the project and who should lead at any particular moment. The uncertainty of the staff member, which meant that she did not reach out to the student and encourage her to pursue her original project idea, resulted in the project not fitting with the aims of the department.

The student on this project (and others, particularly case study 2 ) held the perception that staff were too busy to contribute. While this might be true of most higher education administrators at any university in the world, this posed a limited, narrow view on the project. This reflects both a lack of communication and a lack of plurality, with students' inability to recognise staff contributions necessary to ensure the project's sustainability. This was an important lesson to learn in thinking about partnership projects existing within a term and beyond it. It is not just about what happened when they were conducting the project, but its sustainability, which would require the input and sense of ownership of the staff member involved.

\section{Responsibility for sustaining the project}

The question of who is responsible for sustaining the project, raised by the second case study, is perhaps a false one: There should be collective responsibility, which as discussed above is built through more a collective definition of the project and through the 
students involving staff more in its delivery. Sustainability is difficult to deliver without staff involvement, as students have other commitments, such as the year abroad in this case, and a limited time at the university. Staff are likely to have a greater understanding of how changes occur in their contexts: which forms to fill in, who to ask for help and when, or what constraints exist. Having said this, Dan's project's sustainability would have been aided by a systematic evaluation of the pilot to make an evidence-based claim for its continuation and the benefits it posed to core modules.

\section{Trust}

Case study 3 reminds us of the vulnerability of staff in working with students as partners. Crawford (2012) discusses how staff were concerned about whether the findings of student consultants on teaching would be used against them in performance reviews. Cook-Sather (2014) also discusses staff seeing student consultants as threatening when they do not view them as partners. Staff in the department where the "Syllabus Overlaps" project occurred, have the perception that students used their findings against them in the National Student Survey. Whereas one might be able to guarantee that the findings will not be used managerially, it is difficult to guarantee how students will use their findings. The focus instead must be on how to develop a trusting relationship on both sides, where the joint aim is to enhance practice, use findings ethically, and where staff will help to effect change.

\section{What can students achieve?}

As discussed above, the "unethical" reporting in case study 3 may have been due to the students not believing that their work had the power to create change, and so ensured their findings were also reported in the NSS. A lack of belief that students have the power to create change is a problem that was reported in two other projects. The staff partner on case study 4 reported that the project report had not made recommendations in one area because the students felt that change was not possible in that area. The student in case study 1 reported difficulty getting other students to participate in the project because they did not believe that change could be achieved. This speaks to the lack of student partnership culture that existed at the time. It is therefore vital that the successes of such projects are made visible to students to build belief in their power to influence change.

\section{Time}

One major barrier to the other projects producing a sustainable outcome was poor time management. The projects started throughout the year, and while many students planned to continue their projects following the exam period, this did not happen. As a result, two of the projects did not produce outputs in the form of recommendations that could be used. As a result, UCL ChangeMakers now asks for all projects involving undergraduates to be completed prior to the exam period and provides training on time management.

\section{CONCLUSION}

Student-staff partnerships bring many benefits to higher education. The lessons learned from these case studies informed the subsequent ChangeMaker projects, particularly in emphasising what goes into a successful partnership in order to enact meaningful change: 
1. Students and staff need to recognise and commit to the idea of partnership as crucial to the project's sustained success. The projects may be successful in the short term without staff input, but they are unlikely to be sustainable if students do not create collective responsibility for the project by involving staff.

2. Partnership schemes need to emphasise and explore with students and staff the multidimensional aspects of partnership work. For example, students need to acknowledge that a staff member's schedule might limit the time available to discuss project progress; yet, the nature of staff work means that they have experience and administrative knowledge that is important for effecting longer-term impact. Inversely, staff need to acknowledge and accept that students might not have developed these requisite project management skills; therefore, extra time and explanation might be needed to bring students into these processes. However, students have current experience of being taught at a university and a perspective that encompasses not only the course being taught but the whole programme and student experience, which is important for understanding how best to implement positive change for students. Recognizing partnership work as multidimensional requires each partner to understand each other's strengths and constraints.

3. Students need to think carefully (with support) about choosing the appropriate staff member to work with them on the project rather than advise them. This evaluation is not intended to imply that students should not initiate or drive their own enhancement projects, as per the students-as-change-agents model; this is still an important part of the UCL ChangeMakers ethos. However, the impetus for change will not be sustained unless students find the appropriate partners in carrying out their work.

4. Uncertainty about roles can be paralysing: Staff may fear disempowering students by trying to redirect their work towards something that will have lasting impact while students may struggle to challenge staff to question embedded and cherished practices, particularly when students perceive staff as experienced or powerful. Staff and students may need the reassurance that they do not always have to achieve a perfect partnership. Staff need to involve students and empower them as best befits the context in which they work. Usually, that will involve empowering students more than they currently are, but not in all cases.

5. Honesty is required in terms of what is useful for staff/departments as well as about the uncertainty that exists for staff and students in how to act in partnerships when this practice is new to them. Honesty helps to develop trust-trust that students will use the findings fairly and trust that staff are serious about the possibility of implementing change based on the project-which is vital to successful partnership.

6. Finally, it is important to envision the sustained impact of the partnership by closing feedback loops and informing students of the project's impact after it ends. Through this last aspect of partnership, communication beyond graduation (or during a study abroad) further empowers the students and staff to recognise their contributions to enhancing educational practices.

Before conducting the interviews and surveys cited in this research article, the university's research ethics board successfully reviewed and approved research efforts conducted within the researchers' academic centre. 


\section{NOTE ON CONTRIBUTORS}

Jenny Marie has directed UCL ChangeMakers since 2015. As well as her interest in studentstaff partnership, she is interested in the enhancement of assessment and feedback and is currently part of UCL's Assessment Review team.

Susannah McGowan is a Teaching Fellow in the King's Learning Institute at King's College London. Prior to this position she worked at the University College London Arena Centre for Research-based Education and the Center for New Designs in Learning and Scholarship at Georgetown University in the United States. Since beginning this article, she moved from UCL to King's College London.

\section{REFERENCES}

Åkesson, E., \& Malmberg, A. (2012). Preface. In J. Gärdebo, \& M. Wiggberg (Eds.), Students, the university's unspent resource: Revolutionising higher education through active student participation (pp. 3-6). Uppsala University: Report series from the Division for Development of Teaching and Learning, number 12.

Allin, L. (2014). Collaboration between staff and students in the scholarship of teaching and learning: The potential and the problems. Teaching \& Learning Inquiry, 2(1), 95-102.

Andersson, S. (2012). Hearing the call for active student participation. In J. Gärdebo, \& M. Wiggberg (Eds.), Students, the university's unspent resource: Revolutionising higher education through active student participation (pp. 19-30). Uppsala University: Report series from the Division for Development of Teaching and Learning, number 12.

Bergmark, U., \& Westman, S. (2016). Co-creating curriculum in higher education: Promoting democratic values and a multidimensional view on learning. International Journal for Academic Development, 21(1), 28-40. http://dx.doi.org/10.1080/1360144X.2015.1120734

Bovill, C., \& Bulley, C.J. (2011). A model of active student participation in curriculum design: Exploring desirability and possibility. In C. Rust. (Ed.), Improving student learning (ISL) 18: Global theories and local practices: Institutional, disciplinary and cultural variations (pp. 176-188). Series: Improving Student Learning. Oxford: Oxford Brookes University.

Bovill, C., Cook-Sather, A., Felten, P., Millard, L., \& Moore-Cherry, N. (2015). Addressing potential challenges in co-creating learning and teaching: Overcoming resistance, navigating institutional norms and ensuring inclusivity in student-staff partnerships. Higher Education, 71(2), 195-208. http://dx.doi.org/10.1007/s10734-015-9896-4h

Brooman, S., Darwent, S., \& Pimor, A. (2015). The student voice in higher education curriculum design: Is there value in listening? Innovations in Education and Teaching International, 52(6), 663-674. http://dx.doi.org/10.1080/14703297.2014.910128

Carey, P. (2013). Student as co-producer in a marketised higher education system: A case study of students' experience of participation in curriculum design. Innovations in Education and Teaching International, 50(3), 250-260. http://dx.doi.org/10.1080/14703297.2013.796714

Charmaz, K. (2014). Constructing grounded theory. ( $2^{\text {nd }}$ ed.) Thousand Oaks, California: Sage. 
Cook-Sather, A. (2014). Student-faculty partnership in explorations of pedagogical practice: A threshold concept in academic development. International Journal for Academic Development, 19(3), 186-198. http://dx.doi.org/10.1080/1360144X.2013.805694

Cook-Sather, A., Bovill, C., \& Felten, P. (2014). Engaging students as partners in learning and teaching: A guide for faculty. San Francisco: Jossey-Bass.

Crawford, K. (2012). Rethinking the student-teacher nexus: Students as consultants on teaching in higher education. In M. Neary, H. Stevenson, \& L Bell (Eds.), Towards teaching in public: Reshaping the modern university. London: Bloomsbury.

Dunne, E., \& Zandstra, R. (2011). Students as change agents: New ways of engaging with learning and teaching in higher education. Bristol: Higher Education Academy.

El-Hakim, Y., King, S., Lowe, T. \& Sims, S. (2016). Evaluating partnership and impact in the first year of the Student Fellows Scheme. Journal of Educational Innovation, Partnership and Change, 2(1). Retrieved from: https://journals.gre.ac.uk/index.php/studentchangeagents/article/view/257

Higher Education Academy. (2014). Framework for partnership in learning and teaching in higher education. York: Higher Education Academy. Retrieved from: https://www.heacademy.ac.uk/students-partners-framework-action

Healey, M., Flint, A., \& Harrington, K. (2014). Developing students as partners in learning and teaching in higher education. York: Higher Education Academy.

Healey, M., Flint, A., \& Harrington, K. (2016). Students as partners: Reflections on a conceptual model. Teaching \& Learning Inquiry, 4(2), 1-13.

http://dx.doi.org/10.20343/teachlearninqu.4.2.3

Jarvis, J., Dickerson, C., \& Stockwell, L. (2013). Staff-student partnership in practice in higher education: The impact on learning and teaching. Procedia - Social and Behavioral Sciences, 90(10), 220-225. https://doi.org/10.1016/i.sbspro.2013.07.085

Maunder, R. (2015). Working with students as partners in pedagogic research: Staff and student experiences of participating in an institutional bursary scheme. Journal of Educational Innovation, Partnership and Change, 1(1), 1-7. http://dx.doi.org/10.21100/jeipc.v1i1.162

Mihans, R. J.; Long, D. T., \& Felten, P. (2008) Power and expertise: Student-faculty collaboration in course design and the scholarship of teaching and learning. International Journal for the Scholarship of Teaching and Learning, 2(2), 1-9. https://doi.org/10.20429/ijsotl.2008.020216

UCL. (2014). UCL 2034: A new 20-year strategy for UCL (UCL strategy document). Retrieved from University College London website http://www.ucl.ac.uk/2034.

\section{APPENDIX 1}

1: Are you glad you undertook a UCL ChangeMaker Project?

2: Was it enjoyable to undertake a UCL ChangeMaker Project?

3: Would you recommend UCL ChangeMaker Projects to other students who are interested in making a change at UCL?

4: What advice would you give to another student who was thinking of doing a UCL ChangeMaker Project?

5: How would you rate UCL ChangeMaker Projects? Rate between 1-5, where 5 is excellent.

6: Has running a UCL ChangeMaker Projects improved your experience at UCL? 
7: Approximately how many hours in total did your project take?

8: What was your motivation for taking part?

9: How confident are you that your change will take place? Why? Rate between 1-5, where 5 is very confident.

10: What barriers did you encounter?

11: Do you think the payment to project leads of $£ 150$ is a fair amount given the time and effort put in?

12: Do you think payment of $£ 50$ to project supports was a fair amount?

13: Is getting recognised on the Higher Education Achievement Record (HEAR) a good incentive for taking part?

14: Funding: please select all the statements you agree with:

The amount of funding was fair

The funding covered my project expenses

It was clear what the funding covered

It was easy to gain access to the funding

The amount of funding limited what I was able to do in my project

It was easy to find out how much money I had spent

It was easy to find out how much money I had left

Any other comments about funding.

15: Did you feel supported?

16: What support did you find useful?

17: What other support would have been useful if it had been available?

18: If we were to run an initial training workshop, what do you think should be included in it that would have helped you with your project?

19: How could we have created more of a community feel?

20: Any other comments or suggestions for us to take into consideration for the development of UCL ChangeMaker Projects?

${ }^{\mathrm{i}}$ Pseudonyms are used in this article to protect the identities of participants. 